Technological University Dublin

DƯBLIN

ARROW@TU Dublin

Articles

Crest: Centre for Research in Engineering

Surface Technology

2015-07-26

\title{
Protective Properties of Functionalised Tetrazine on an Aerospace Aluminium Alloy (AA 2024-T3)
}

\author{
Swarna Jaiswal \\ Technological University Dublin, swarna.jaiswal@tudublin.ie \\ P.C. Rajath Varma \\ Technological University Dublin, rajath.varma@tudublin.ie \\ Brendan Duffy \\ Technological University Dublin, brendan.duffy@tudublin.ie
}

See next page for additional authors

Follow this and additional works at: https://arrow.tudublin.ie/cenresart

Part of the Microbiology Commons

\section{Recommended Citation}

Jaiswal S*, Varma PCR,Felicia Mutuma, McHale P, Duffy B. (2015) Protective properties of functionalised tetrazine on an aerospace aluminium alloy (AA 2024-T3). Materials Chemistry and Physics 163, 90-200. doi:10.1016/j.matchemphys.2015.07.029

This Article is brought to you for free and open access by the Crest: Centre for Research in Engineering Surface Technology at ARROW@TU Dublin. It has been accepted for inclusion in Articles by an authorized administrator of ARROW@TU Dublin. For more information, please contact arrow.admin@tudublin.ie, aisling.coyne@tudublin.ie,gerard.connolly@tudublin.ie.

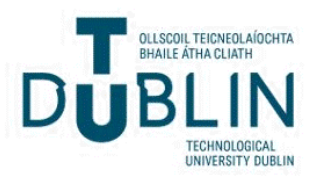


Authors

Swarna Jaiswal, P.C. Rajath Varma, Brendan Duffy, Felicia Mutuma, and Patrick McHale

This article is available at ARROW@TU Dublin: https://arrow.tudublin.ie/cenresart/44 
Materials Chemistry and Physics 163, (2015) 190-200.

Protective properties of functionalised tetrazine on an aerospace aluminium alloy (AA 2024-T3)

Swarna Jaiswal ${ }^{\mathrm{a}, \mathrm{b} *}$, P.C. Rajath Varma ${ }^{\mathrm{a}}$, Felicia Mutuma ${ }^{\mathrm{a}, \mathrm{c}}$, Patrick McHale ${ }^{\mathrm{b}}$, Brendan Duffy ${ }^{\mathrm{a}}$

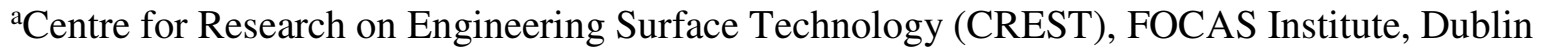
Institute of Technology, 13 Camden Row, Dublin 8, Ireland

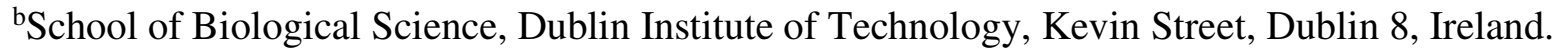

${ }^{\mathrm{c} S c h o o l ~ o f ~ C h e m i c a l ~ a n d ~ P h a r m a c e u t i c a l ~ S c i e n c e s, ~ D u b l i n ~ I n s t i t u t e ~ o f ~ T e c h n o l o g y, ~ K e v i n ~ S t r e e t, ~}$ Dublin 8, Ireland.

*Corresponding author. Tel.: +3531402 7948; fax: +35314027941.

E-mail address: swarna.jaiswal@dit.ie (Swarna Jaiswal) 


\begin{abstract}
Environmental health concerns over conventional chromium based surface treatments on aluminium substrates are well known. Current research efforts have concentrated on developing protective technologies for multiple applications. Such properties would enable manufacturers to address both corrosion and bacterial threats in areas such as fuel tanks and delivery systems.

The present study explores the anticorrosion properties of 1,2-dihydro 1,2, 4, 5 tetrazine-3, 6dicarboxylic acid $\left(\mathrm{H}_{2}\right.$ DCTZ) on a copper rich aerospace aluminum alloy (AA 2024-T3). Furthermore the antimicrobial activity of the tetrazine is evaluated against Gram-positive and Gram-negative bacteria, both capable of inducing corrosion. The protective action of the tetrazine was investigated at different concentrations in a chloride ion rich environment $3.5 \%$ (w/v) $\mathrm{NaCl}$ ) utilising electrochemical impedance spectroscopy (EIS). Results over a 72 hour period proved that an optimum concentration was $500 \mathrm{ppm}$. FTIR and SEM elemental mapping of the surface confirmed the nitrogen rich tetrazine affinity for the copper rich intermetallic sites, through coordinate bonds, which delayed corrosion onset and reduced pit formation. Moderate antibacterial tetrazine activity was observed against Escherichia coli and 100\% efficacy against Staphylococcus aureus at $250 \mathrm{ppm}$ was achieved. The damage of the bacterial cell envelope at the critical concentrations $(250 \mathrm{ppm})$ is proposed as a possible mechanism for antibacterial action.
\end{abstract}

Keywords; Alloy; Corrosion; Surface properties; Electrochemical Technique; Fourier Transform Infrared Spectroscopy (FTIR) 


\section{Introduction}

The elimination of carcinogenic hexavalent chromium as a corrosion inhibitor for aluminium alloys has been of urgent concern in the aerospace industry [1,2]. The industry relies on chromates in surface treatments (conversion coatings, anodising) and primer coatings due to its corrosion inhibition properties. These properties are based on the reactivity of $\mathrm{Cr}(\mathrm{VI})$ and the stability of its $\operatorname{Cr}(\mathrm{III})$ state, based on its d-shell chemistry $[3,4]$. As such the chemical reactivity means that $\mathrm{Cr}(\mathrm{VI})$ is a strong carcinogen.

Nitrogen rich heterocycles are one of the most likely chromium replacements, and are good corrosion inhibitors for many metals and alloys in different aggressive mediums. In particular, N-rich heterocycles display a strong affinity for copper intermetallic sites on engineering aluminium alloys. Previously derivatives of indole were used to prevent corrosion of mild steel or copper in acidic media [5], while pyridazine derivatives [6, 7] as well as triazole and thiazole derivatives [8] are well known corrosion inhibitors for copper and its alloy in chloride solutions. Coincidently, derivatives of 1,2,4-triazole and 1,2,4-triazine, whose family members are known anticorrosion agents, have been found to possess wide spectrum of pharmacological, medicinal and biological activities $[9,10,11]$. Therefore the synergies of such nitrogen rich corrosion inhibitors as biologically active species can have beneficial applications in the aerospace industry where microbially induced corrosion can occur, within confined spaces such as the airframe and tank environs (environments).

Tetrazines are nitrogen rich six membered aromatic compounds with a very high electron affinity. 1,2,4,5-Tetrazine (s-tetrazine) and its 3,6-disubstituted derivatives display a particular coordination chemistry, distinguished by electron and charge transfer phenomena [12]. The attractive properties of s-tetrazines and their derivatives are due to the nitrogen atoms offering 
excellent $\pi$ acceptor capacity (for $\pi$ back-donation from low-valence metals) with poor $\sigma$ basicity enabling molecules to form stable metal-metal bridging structures (Fig.1). Until lately the anticorrosion properties of tetrazine derivatives had only been investigated on steels [13], where 3,6-bis(2-methoxyphenyl)-1,2-dihydro-1,2,4,5-tetrazine (2-MDHT) displayed effective inhibitor performance on mild steel immersed in an acidic medium. More recently the authors investigated two tetrazines with anticorrosion activity on steel with synergistic antibacterial performance [14]. Further research positively compared commercial tetrazines with two azoles as corrosion inhibitors in anodised aluminium oxide layers [15].

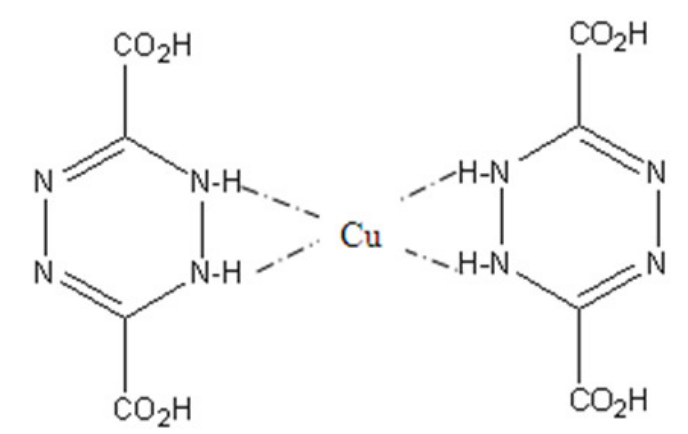

Fig. 1 Formation of Cu-DCTZ complex structure

s-Tetrazines possess significant biological properties [16, 17 18]. For example 3-arylamino-6benzylamino-1,2,4,5-tetrazines have potent antimalarial activity [19], while some hexahydro-stetrazines are useful analgesics and anti-inflammatories [20]. The antibacterial [14] and antifungal activities [21] of a series of tetrahydro-s-tetrazines have also been reported, with some 1,4-dihydro-s-tetrazine derivatives having pronounced antiviral and antitumor activity [22].

The present study explores the anticorrosion properties of 1,2-dihydro 1,2, 4, 5 tetrazine-3, 6dicarboxylic acid $\left(\mathrm{H}_{2}\right.$ DCTZ) on a copper rich aerospace aluminum alloy (AA 2024-T3). Furthermore the antimicrobial activity of the tetrazine is evaluated against Gram-positive and 
Gram-negative bacteria, both capable of inducing corrosion. Fourier transform infrared spectroscopy (FTIR), Field Emission Scanning electron microscopy and energy dispersive X-ray spectrometer (FE-SEM-EDS) were used to map the mobility of the tetrazine at a copper rich intermetallic site. Antibacterial studies were carried out against corrosion inducing Staphylococcus aureus ATCC 25923 and Escherichia coli ATCC 25922 bacteria [23]. Additionally, the release of malondialdehyde (MDA) by the bacteria was measured and used as an indicator of damage to bacterial membranes caused by the $\mathrm{H}_{2}$ DCTZ.

\section{Materials and Methods}

\subsection{Tetrazine synthesis}

1,2-dihydro 1, 2, 4, 5-tetrazine-3, 6-dicarboxylic acid $\left(\mathrm{H}_{2} \mathrm{DCTZ}\right)$ was synthesised using a reported method [24] and its structure was confirmed by Nuclear Magnetic Resonance Spectroscopy (NMR) and Fourier Transform Infrared Spectroscopy (FTIR) [25].

\subsubsection{Procedure}

Sodium hydroxide $(3.15 \mathrm{~g}, 76.5 \mathrm{mmol})$ and $2.5 \mathrm{ml}$ water were added to 11 round bottomed flask equipped with a stirrer, thermometer and a funnel. Ethyl diazoacetate $(2 \mathrm{~g}, 17 \mathrm{mmol})$ was added to the solution drop wise and the resulting slurry left to cool to the room temperature. Upon cooling the solution was poured into $10 \mathrm{ml}$ ethanol $(95 \%)$ and the liquid decanted. The washing procedure was repeated 5 times. The resulting precipitate was collected by vacuum filtration. The solid was further washed with $10 \mathrm{ml}$ ether and dried to afford disodium dihydro-1,2,4,5tetrazine-3,6-dicarboxylate $(1.5 \mathrm{~g}, 8.1 \mathrm{mmol})$ as a yellow solid. This was transferred to a round bottomed flask equipped with a stirrer and $4 \mathrm{ml}$ ice cold water added. The resulting slurry was cooled to room temperature in an ice bath and concentrated hydrochloric acid added $(1.5 \mathrm{ml}$, $37 \%$ ) drop wise. The reaction mixture was washed using $4 \mathrm{ml}$ ether and the ether layer decanted. 
The product was immediately isolated via vacuum filtration and dried at room temperature to afford 0.84g (60\%) 1,2-dihydro 1, 2, 4, 5-tetrazine-3, 6-dicarboxylic acid as a yellow powder [26]

\subsubsection{NMR Characterisation}

A Bruker Avance $400 \mathrm{MHz}$ spectrometer equipped with a ${ }^{1} \mathrm{H} /{ }^{13} \mathrm{C}$ dual probe was used for the measurement. NMR was performed at room temperature in deuterated dimethyl sulfoxide (DMSO-d6) using tetramethylsilane as an internal standard.

The measurement was carried out with the real pulse of $3.5 \mu$ s and $3.4 \mu$ s for the proton and carbon respectively. The spectral width of $24038 \mathrm{~Hz}$ was used for the analysis. The pre scan delay time and acquisition time was recorded $6.5 \mu \mathrm{s}$ and $1.36 \mathrm{sec}$ respectively. The zero filling was used for the data acquisition and the relaxation delay for ${ }^{13} \mathrm{C}$ analysis was $2 \mathrm{~s}$.

\subsection{Evaluation of anticorrosion properties}

The anticorrosion properties were evaluated by Electrochemical Impedance Spectroscopy (EIS), FT-IR and FE-SEM-EDX. Before analysis AA2024-T3 aluminium panels and subsequent electrochemical cells were prepared.

\subsubsection{Panel preparation}

AA2024-T3 aluminium panels (150 mm x $100 \mathrm{~mm})$ were sourced from Amari Irl, Clondalkin (Irl). The panels were degreased with isopropanol, alkaline cleaned using Oakite $61 \mathrm{~B}^{\circledR}$ (Chemetall, UK) by immersion at $60-70^{\circ} \mathrm{C}$ for $1 \mathrm{~min}$ and washed with deionised water at ambient temperature and air dried. 


\subsubsection{Electrochemical cell analysis}

Electrochemical data was obtained using a Solartron SI 1287 comprising with 1255B frequency response analyser. The software core view and $\mathrm{Z}$ plot were used for the data analysis. EIS was performed using the electrochemical cells prepared by mounting bottom-less plastic vials on to the exposed surface of the aluminium panel $\left(4.9 \mathrm{~cm}^{2}\right)$ with amine hardened epoxy glue $\left(\right.$ Araldite $\left.^{\circledR}\right)[27]$.

EIS is a technique that can simultaneously provide information on the corrosion mechanism and assess the corrosion protection provided by a metal substrate. The EIS spectrum is frequency dependant and is dominated by the properties of the electrolyte $\left(>\sim 10^{5} \mathrm{~Hz}\right)$, coating $\left(\sim 10^{0}-10^{5}\right.$ $\mathrm{Hz})$ and surface interactions $\left(<\sim 10^{0} \mathrm{~Hz}\right)$. Effective barrier coatings display impedance values of at least $10^{6} \mathrm{Wcm}^{2}$ at lower frequencies $\left(\leq 10^{-2} \mathrm{~Hz}\right)$, implying low rates of electrochemical activity and hence lower corrosion rates [27].

The experimental set up consisted of a 3 electrode cell with the metal substrate acting as the working electrode. A silver/silver chloride $(\mathrm{Ag} / \mathrm{AgCl})$ electrode and platinum mesh were used for reference and counter electrodes respectively. The dry aluminium substrate was exposed to different concentrations of $\mathrm{H}_{2} \mathrm{DCTZ}((0-1,000 \mathrm{ppm})$ dissolved in $3.5 \%(\mathrm{w} / \mathrm{v}) \mathrm{NaCl})$ solution at the ambient temperature $\left(25^{\circ} \mathrm{C}\right)$ All measurements were made at the open circuit potential (OCP, $\mathrm{E}_{o c}$ ) with an applied $10 \mathrm{mV}$ sinusoidal perturbation in the frequency range $1 \times 10^{6}$ to $1 \times 10^{-2} \mathrm{~Hz}$ (10 points per decade). Simulation of the electrochemical data with an equivalent circuit model (ECM) [28] was performed using Z View ${ }^{\circledR}$ software. All the experiments were performed in triplicate at ambient temperature $\left(20 \pm 2^{\circ} \mathrm{C}\right)$. 


\subsubsection{FTIR study}

FTIR spectroscopy is an established technique used to study interfaces, polymer blends and physical chemical processes. It can also be used to locate the distribution of chemical functional groups within a sample domain. In the present study FTIR spectroscopy was used to determine the affinity of $\mathrm{H}_{2} \mathrm{DCTZ}$ to the copper rich intermetallics at the surface of the AA 2024-T3 alloy. Chemical mapping of the surface by FTIR was performed using a Perkin Elmer Spotlight 400 instrument operating in the transmission mode. The spectra were measured in the range of 4000$650 \mathrm{~cm}^{-1}$ with a scan resolution of $4 \mathrm{~cm}^{-1}$. The wavenumber $1635 \mathrm{~cm}^{-1}$ was selected for the recording of the mapping. The illuminated area on the sample is defined by the projected apparatus size of $10 \mu \mathrm{m} \times 10 \mu \mathrm{m}$. Spectroscopic mapping was performed directly on a selected area $(485 \mu \mathrm{m} \times 335 \mu \mathrm{m})$ in the vicinity of a corrosion pit by a 16 pixel linear array with a pixel resolution of $6.25 \mu \mathrm{m}$.

\subsection{FE-SEM-EDX study}

FE-SEM analysis and X-ray dot mapping were completed using a Hitachi SU-70 Field emission microscope operating at electron beam energy of $20 \mathrm{keV}$. The FE-SEM was equipped with EDX spectrometer (Oxford instrument INCAx-act 450 system fitted with silicon drift detector). The energy dispersive array detector was used to map the distribution of $\mathrm{Cu}$ around the corrosion pit region selected from the FTIR analysis described above. The corrosion pit region formed in the presence of $500 \mathrm{ppm} \mathrm{H}_{2}$ DCTZ (3.5\% (w/v) $\mathrm{NaCl}$ ) was examined by FTIR analysis and used for the SEM/EDX experiments. The area of interest was polished with $3 \mu \mathrm{m}$ diamond paste and then washed with high pressure running water to remove surface corrosion product before being rapidly air dried at $100^{\circ} \mathrm{C}$. 


\subsection{Evaluation of antibacterial activity}

The antibacterial activities minimum inhibitory concentration (MIC), minimum bactericidal concentration (MBC) and bacterial growth kinetics of the $\mathrm{H}_{2} \mathrm{DCTZ}$ were assessed using a microdilution broth method [29].

\subsubsection{Bacterial strains and growth conditions}

The bacterial strains used in this study included Gram positive (Staphylococcus aureus ATCC 25923) and Gram negative (Escherichia coli ATCC 25922) bacteria. Staphylococcus aureus and Escherichia coli are both known to induce corrosion in hydrocarbon rich fuel environments as found in aerospace fuel tanks [23]. The cultures were grown, sub-cultured and maintained on Mueller-Hinton agar (MHA) (LAB M) and stored at $4{ }^{\circ} \mathrm{C}$. For these experiments, a single colony of each organism was inoculated into Mueller-Hinton broth (MHB, $10 \mathrm{ml}$ ) and incubated overnight $(24 \mathrm{~h})$ at $37^{\circ} \mathrm{C}$ with shaking at $200 \mathrm{rpm}$. The (Optical Density) $\mathrm{OD}_{600}$ of the culture was adjusted to 0.132 (corresponding to $1 \times 10^{8}$ colony-forming unit $\left(\mathrm{CFU} \mathrm{ml}{ }^{-1}\right)$ ) using sterile MHB and further diluted to give a final working concentration of $1.5 \times 10^{6} \mathrm{CFU} \mathrm{ml}{ }^{-1}$.

\subsubsection{Antibacterial assay}

The antibacterial activities of $\mathrm{H}_{2} \mathrm{DCTZ}$ at different concentrations $(500,250,125,63$ and 32 ppm) against the test organisms were evaluated by a microdilution method using 96-well microtiter plates [29]. Test bacteria $(100 \mu \mathrm{l})$ from the $1.5 \times 10^{6} \mathrm{CFU} \mathrm{ml}^{-1}$ suspensions were added to all wells. A negative control well series containing $\mathrm{H}_{2}$ DCTZ (100 $\left.\left.\mu 1,32-500 \mathrm{ppm}\right)\right)$ and sterile MHB $(100 \mu \mathrm{l})$ and a positive control well containing sterile MHB $(100 \mu \mathrm{l})$ and bacterial suspension $(100 \mu \mathrm{l})$ without $\mathrm{H}_{2}$ DCTZ were included in each assay. One well of the microtiter plate containing sterile MHB $(200 \mu \mathrm{l})$ served as a blank to check for contamination. The microtiter plates were incubated for $24 \mathrm{~h}$ in a microtiter plate reader (Power Wave micro plate 
Spectrophotometer, Biotek, USA) at $37^{\circ} \mathrm{C}$. All samples were tested in quadruplicate on each microtiter plate and two plates were tested for each organism.

\subsubsection{Analysis of minimum inhibitory concentration (MIC) and minimum bactericidal concentration (MBC)}

The minimum inhibitory concentration (MIC) was read after $24 \mathrm{~h}$ of incubation at $37^{\circ} \mathrm{C}$. The lowest concentration of $\mathrm{H}_{2} \mathrm{DCTZ}$ that completely inhibited bacterial growth was considered to be the minimum inhibitory concentration. The antibacterial activities of the compound were determined by calculating the percentage inhibition of growth using the following formula [30]:

$$
I \%=\frac{\left(C_{24}-C_{0}\right)-\left(T_{24}-T_{0}\right)}{\left(C_{24}-C_{0}\right)} \times 100
$$

where I is the percentage inhibition of growth, $\mathrm{C}_{24}$ is the blank compensated $\mathrm{OD}_{600}$ of positive control of the organism at $24 \mathrm{~h}, \mathrm{C}_{0}$ is the blank compensated $\mathrm{OD}_{600}$ of positive control of the organism at $0 \mathrm{~h}, \mathrm{~T}_{24}$ is the negative control compensated $\mathrm{OD}_{600}$ of the organism in the presence of test sample at $24 \mathrm{~h}$ and $\mathrm{T}_{0}$ is the negative control compensated $\mathrm{OD}_{600}$ of the organism in the presence of test sample at $0 \mathrm{~h}$.

The lowest concentration that inhibited the visible growth of the used bacterium was defined as the minimum inhibitory concentration (MICs), indicating a $99.5 \%$ efficacy against the original inoculum. The minimum bactericidal concentrations (MBCs) were examined by a modified imprint method, where $10 \mu \mathrm{l}$ of the tested samples with defined $\mathrm{H}_{2}$ DCTZ concentrations were sub-cultured into the MHA plate from the microtiter wells, after 24 hour incubation at $37^{\circ} \mathrm{C}$.

\subsubsection{Kinetic measurement of bacterial growth}

Bacterial growth can be depicted generally by a growth curve which includes a lag phase where bacteria adapt themselves to the growth medium and conditions. Thereafter growth accelerates 
exponentially up to a maximum growth rate before slowing and stopping (stationary period) so that a maximum colony count or asymptote (A) is reached. The characteristic shape of such curves become sigmoidal [31]. During the lag period, individual bacteria mature and grow, but are not yet unable to divide. The extension of the lag phase is probably the most widely used parameter to describe the inhibitory effects of antimicrobial compounds. The bacterial growth kinetics was monitored in the presence of different concentrations of $\mathrm{H}_{2}$ DCTZ. Bacterial concentrations over time were determined for each well by measuring the $\mathrm{OD}_{600}$ every $30 \mathrm{~min}$ following $30 \mathrm{sec}$ agitation driven by Gen5 reader control and data analysis software. Antibacterial kinetics was studied by examining the bacterial growth curve in the presence and absence of $\mathrm{H}_{2} \mathrm{DCTZ}$.

\subsubsection{Assessment of bacterial damage by chemical assay}

Among many lipid peroxidation products malondialdehyde (MDA) and other monoaldehydes (4hydroxynonenal) are the most biologically important [32]. Malondialdehyde in peroxidised biological samples results from the oxidative degradation of polyunsaturated fatty acids with more than two methylene-interrupted double bonds [33]. MDA is very reactive with the amino groups of amines, amino acids, proteins and producing Schiff-bases [34]. Among several methods of MDA quantification, the thiobarbituric acid (TBA) assay is the preferred established technique [32].The release of MDA by the bacteria was measured as an indicator of damage to their membranes caused by the $\mathrm{H}_{2}$ DCTZ. MDA quantification was achieved through its reaction with TBA forming a pink MDA-TBA adduct [35] which has a $\lambda_{\max }$ at $532 \mathrm{~nm}$. Overnight broth cultures $(1 \mathrm{ml})$ of Gram positive $(S$. aureus) bacterial cells were treated with equal volumes of $\mathrm{H}_{2} \mathrm{DCTZ}$ at their MBC value of $250 \mathrm{ppm}$. A broth sample without $\mathrm{H}_{2}$ DCTZ was used as a control. An aliquot $(1 \mathrm{ml})$ of the suspension was mixed with $10 \%(\mathrm{w} / \mathrm{v})$ trichloroacetic acid 
(TCA, $2 \mathrm{ml}$ ) and the solids formed were removed after centrifuging at 11,000 rpm for $35 \mathrm{~min}$. The supernatant was centrifuged for an additional $20 \mathrm{~min}$ to ensure that cells and precipitated proteins were completely removed. Freshly prepared TBA solution $(0.67 \% \mathrm{w} / \mathrm{v}, 3 \mathrm{ml})$ was added to the supernatant. The samples were then incubated in a boiling water bath for $10 \mathrm{~min}$ and cooled. The absorbance of the test and control solutions was recorded at $532 \mathrm{~nm}$ using UV-visNIR spectrophotometer (Perkin Elmer Lambda 900) to measure the level of the MDA-TBA adduct (Chromogen) formed.

\section{Result and Discussion}

\subsection{FTIR and NMR analysis}

The FTIR data of $\mathrm{H}_{2}$ DCTZ showed bands at $3310 \mathrm{~cm}^{-1}$ (N-H broad stretches), $2531 \mathrm{~cm}^{-1}$ $(\mathrm{COOH}$ stretch$), 1710 \mathrm{~cm}^{-1}(\mathrm{C}=\mathrm{O}$ stretch$), 1313 \mathrm{~cm}^{-1}(\mathrm{C}-\mathrm{O}$ stretch $), 1320,1197 \mathrm{~cm}^{-1}(=\mathrm{C}-\mathrm{N})$, 1062, $1002 \mathrm{~cm}^{-1}$ (C-N stretch) (Fig 2) [Error! Bookmark not defined.].

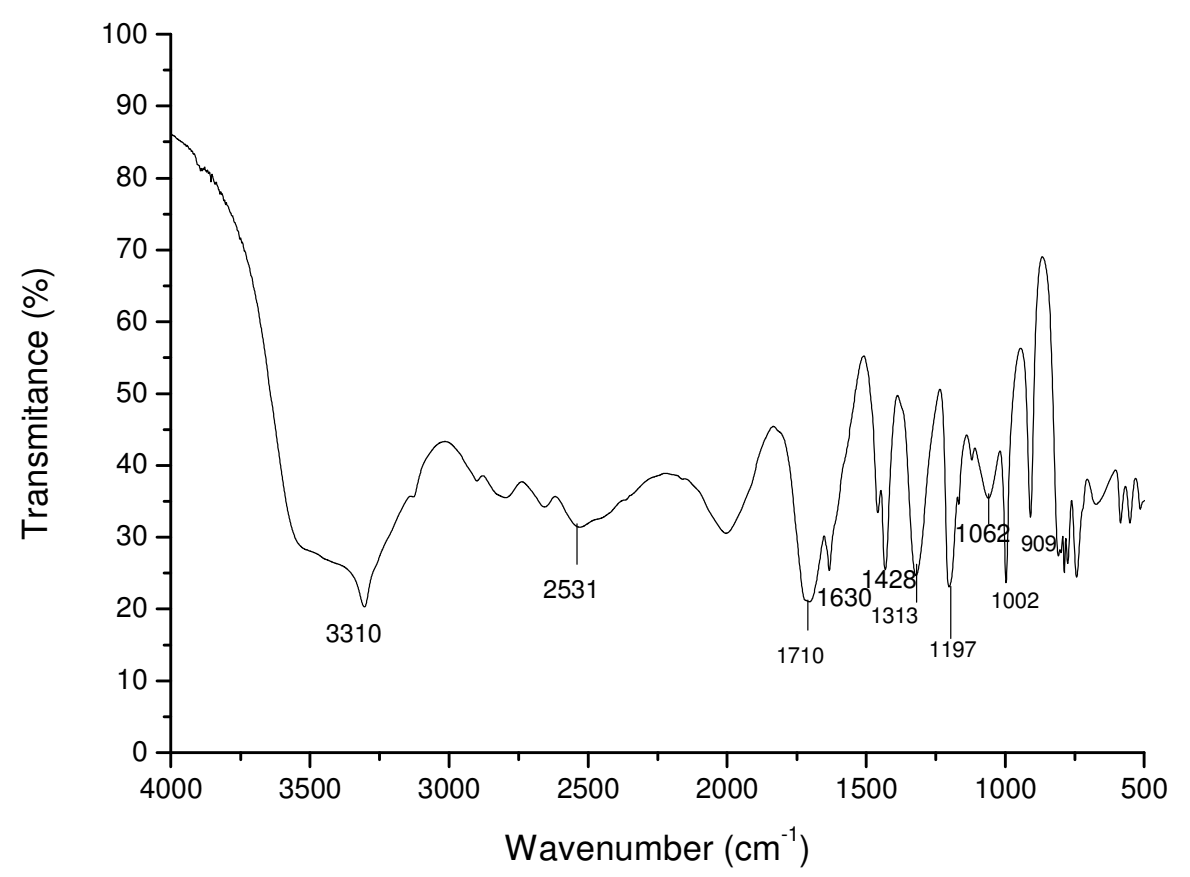

Fig. 2. The characterisation of $\mathrm{H}_{2} \mathrm{DCTZ}$ (1, 2, 4, 5 Tetrazine-3, 6-dicarboylic acid) by FTIR 
The structure of $\mathrm{H}_{2} \mathrm{DCTZ}$ was also established by ${ }^{1} \mathrm{H}$ NMR and ${ }^{13} \mathrm{C}$ NMR. The two amine and two acid protons appear at similar chemical shifts (ppm), hence only two signals are observed on the ${ }^{1} \mathrm{H}$ and ${ }^{13} \mathrm{C}$ NMR spectra. Both types of protons are adjacent to electronegative atoms and therefore, are observed downfield relative to the internal standard tetramethylsilane (TMS). The spectrum was referenced to TMS at 0ppm. ${ }^{1} \mathrm{H}$ NMR (in DMSO-d6): The signal at 2.51-2.50 ppm was assigned to the amine protons $(\mathrm{NH})$. The acid protons $(2 \mathrm{H}, \mathrm{s}, \mathrm{COOH})$, appear even further downfield at $8.87 \mathrm{ppm}$ on the ${ }^{1} \mathrm{H}$ NMR because they are more deshielded by the adjacent oxygen atoms which are more electronegative than the nitrogen (Fig. 3a).

${ }^{13} \mathrm{C}$ NMR (in DMSO-d6): The signal at $139.50 \mathrm{ppm}$ was assigned to the carbons (C-COOH). Further downfield signal at 159.94 ppm was assigned to the carbons (CN) (Fig. 3b).

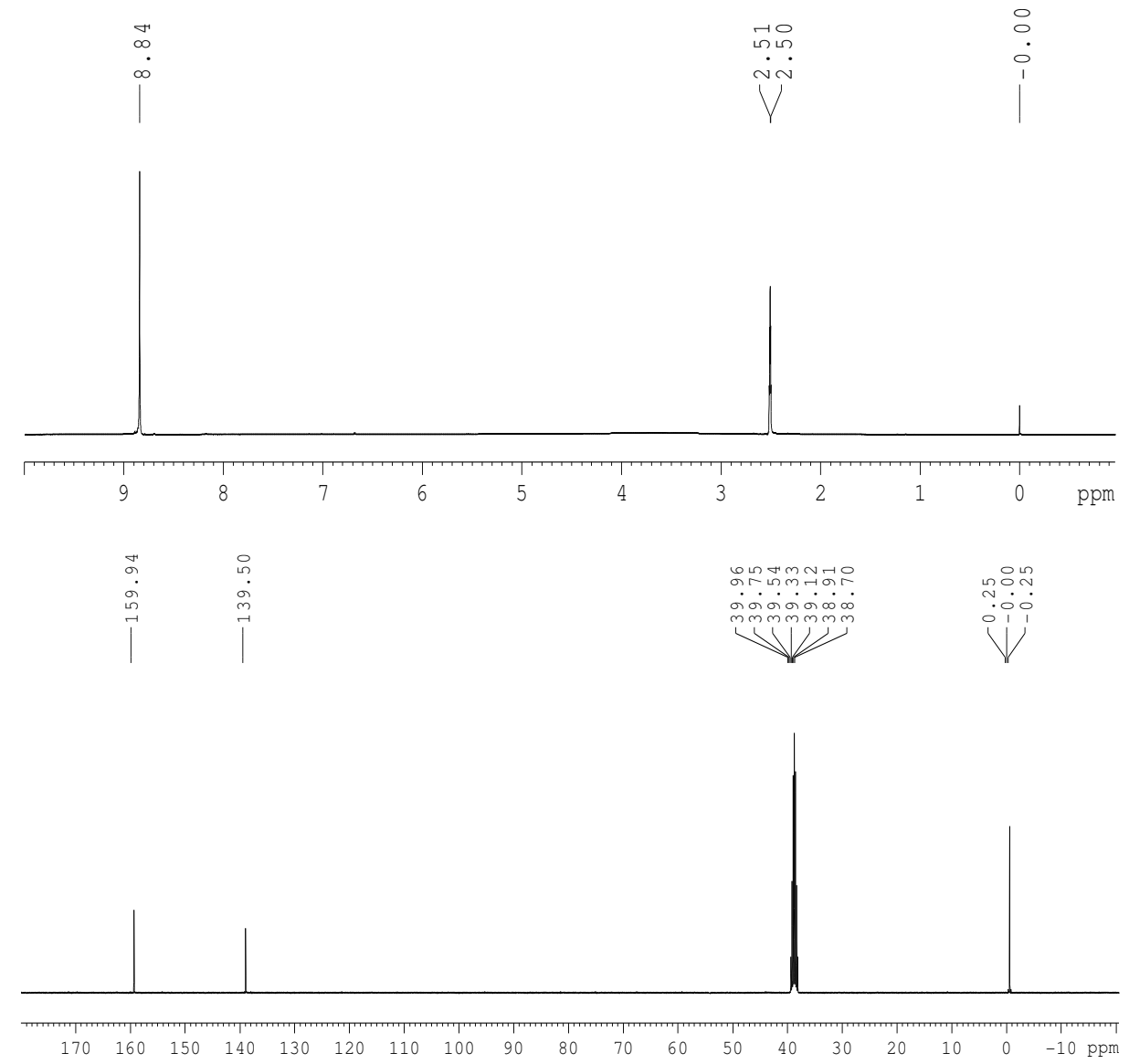

Fig.3. NMR spectra of $\mathrm{H}_{2} \mathrm{DCTZ}$ (a) ${ }^{1} \mathrm{H}$ NMR, (b) ${ }^{13} \mathrm{C}$ NMR 


\subsection{Exposure studies}

The corrosion resistance properties of $\mathrm{H}_{2} \mathrm{DCTZ}$ were visualised by exposure studies of AA2024T3 aluminium panels in direct contact with a salt inhibitor solution $\left(\mathrm{H}_{2} \mathrm{DCTZ}\right.$ concentrations of $0,250,500,750$ and 1,000 ppm) - dissolved in 3.5\% (w/v) $\mathrm{NaCl}$ solution at ambient temperature $\left(25^{\circ} \mathrm{C}\right)$ for a period of 1 week. Optical photographs of the exposed alloy were taken by digital camera (Canon G9, 12.1 mega pixels) (Fig. 4). Varying levels of pitting corrosion can be observed on all surfaces exposed to the electrolyte. All surfaces exposed to the electrolyte containing $\mathrm{H}_{2}$ DCTZ show less corrosion activity when compared to the 0 ppm (blank) sample, although no clear ranking could be made.

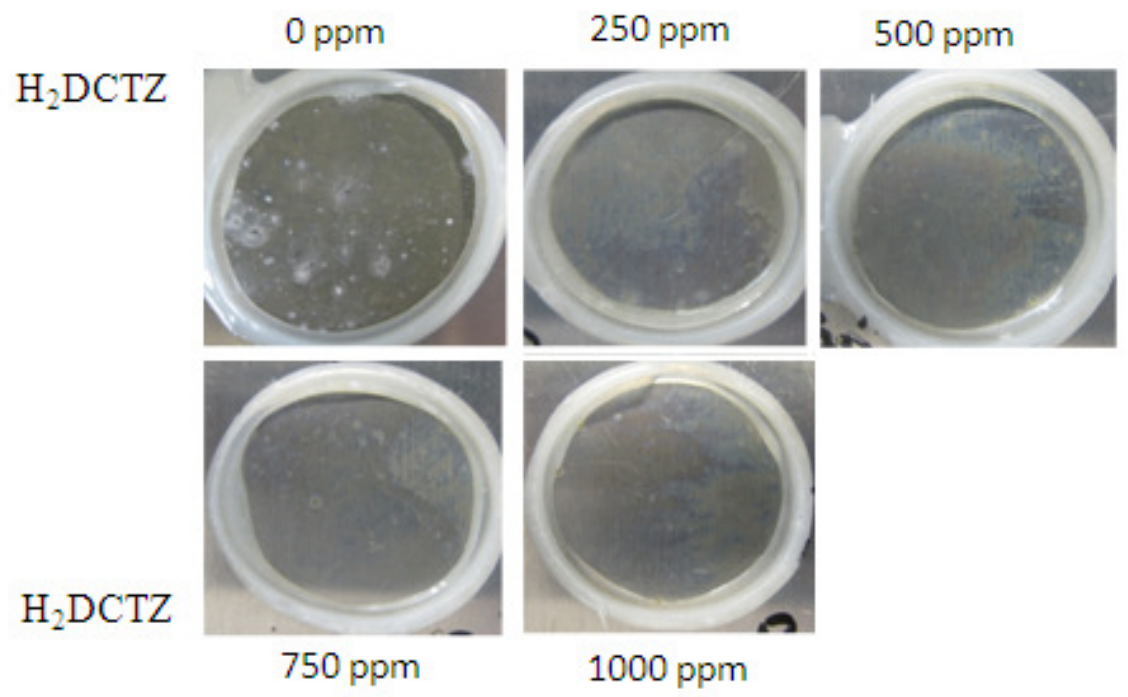

Fig.4 Optical images of AA 2024 alloy exposed to different concentrations (0, 250, 500, 750 and $1000 \mathrm{ppm}$ ) of $\mathrm{H}_{2} \mathrm{DCTZ}$ dissolved in $3.5 \% \mathrm{NaCl}$ after $72 \mathrm{hr}$. (0 ppm refers to only $\left.3.5 \% \mathrm{NaCl}\right)$.

\subsection{Electrochemical studies}

Electrochemical impedance spectroscopy (EIS) is an AC technique used to estimate electrochemical interactions of an exposed metal surface at a preset potential (open circuit potential). EIS can simultaneously provide information on the corrosion mechanism and 
quantitatively assess the corrosion protection provided by $\mathrm{H}_{2} \mathrm{DCTZ}$ [36]. The impedance spectra (Nyquist and Bode plots) of the AA2024 samples were obtained using a series of $\mathrm{H}_{2}$ DCTZ concentrations $(0,250,500,750$ and $1,000 \mathrm{ppm})$ dissolved in a $3.5 \%(\mathrm{w} / \mathrm{v}) \mathrm{NaCl}$ solution. Consistent Nyquist plots were obtained during the initial immersion stage $(0 \mathrm{~h})$ as little surface inhibitor interaction would have occurred (Fig.5a). Initially all Nyquist plots displayed one capacitive arc whereas after $72 \mathrm{~h}$ of electrolyte exposure the impedance spectra of the systems varied significantly (Fig.5b) [37].
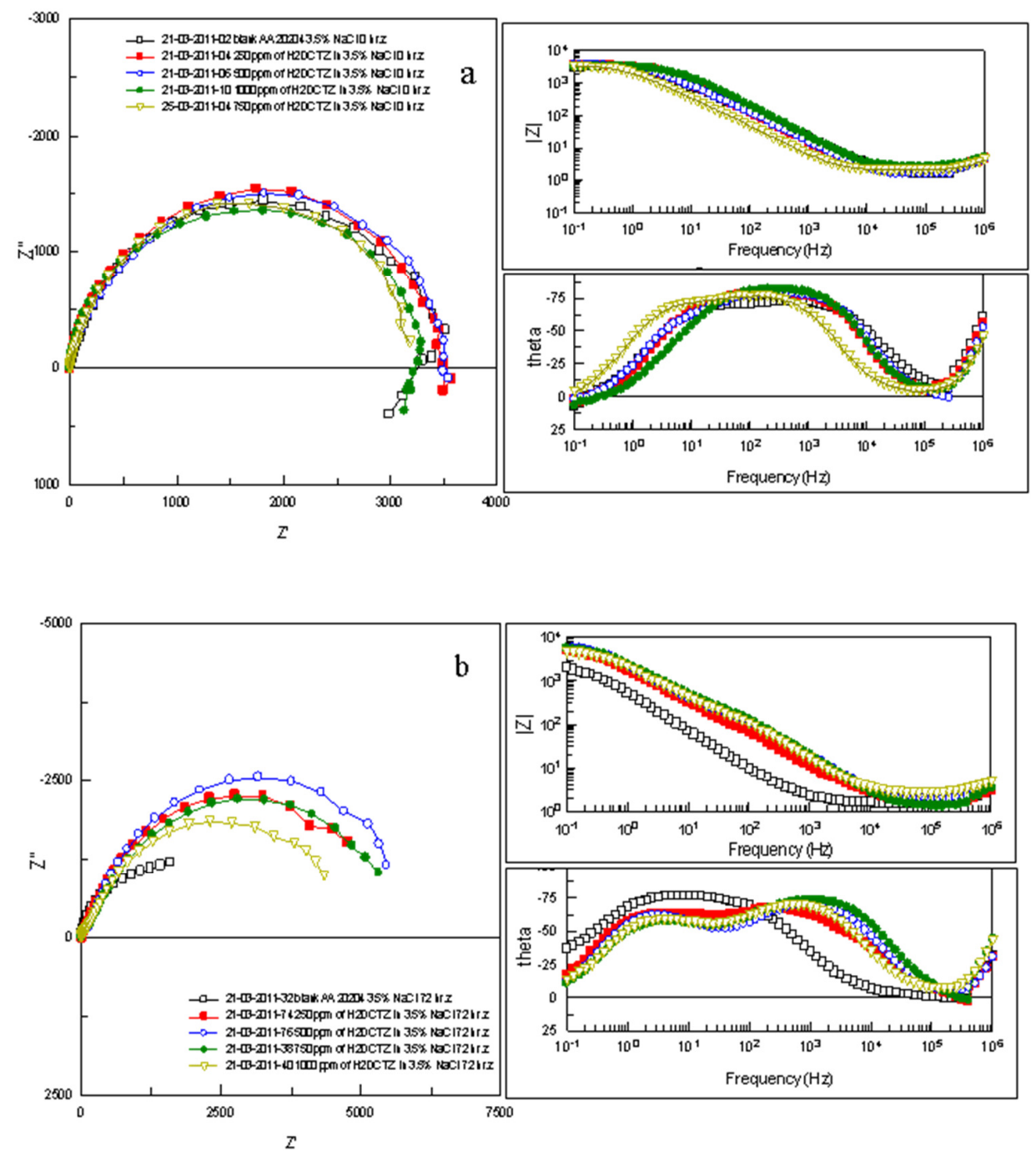
Fig.5 Impedance spectra, Nyquist and Bode plots of the alloy exposed to different concentrations of $\mathrm{H}_{2} \mathrm{DCTZ}$ dissolved in $3.5 \% \mathrm{NaCl}(\mathrm{a}) ,0 \mathrm{~h}(\mathrm{~b}) 72 \mathrm{~h}$.

While the impedance of the 0 ppm system decreased (indicating corrosion activity), the overall impedance of all $\mathrm{H}_{2}$ DCTZ systems increased with 500 ppm showing the highest barrier performance. The order of improvement is $500>250 \approx 750>1000>0 \mathrm{ppm}$. This order indicates that an optimised concentration is achieved at $500 \mathrm{ppm}$ after which the inhibition begins to decrease. A $\mathrm{pH}$ study of the tetrazine solutions at varying concentrations was performed and it was observed that $\mathrm{pH}$ decreases with increasing $\mathrm{H}_{2} \mathrm{DCTZ}$ concentrations when exposed to AA2024-T3 (Table 1). Over the course of $72 \mathrm{~h}$ the $\mathrm{pH}$ of all solutions rose as the tetrazine concentration dropped due to consumption at exposed sites.

Table. 1. $\mathrm{pH}$ measurement of the different concentrations $(0,250,500,750,1000 \mathrm{ppm})$ of $\mathrm{H}_{2} \mathrm{DCTZ}$ on the surface of aluminium panel (AA 2024-T3) over $24 \mathrm{~h}$ time period intervals.

\begin{tabular}{|l|l|l|l|l|l|}
\hline & \multicolumn{5}{|c|}{ Concentrations (ppm) } \\
\hline Time (h) & 0 & $\mathbf{2 5 0}$ & $\mathbf{5 0 0}$ & $\mathbf{7 5 0}$ & $\mathbf{1 0 0 0}$ \\
\hline 0 & 6.58 & 3.66 & 3.27 & 3.12 & 3.01 \\
\hline 24 & 8.17 & 6.88 & 5.19 & 5.01 & 4.83 \\
\hline 48 & 7.9 & 7.51 & 5.47 & 5.28 & 4.97 \\
\hline 72 & 7.92 & 7.87 & 5.99 & 5.73 & 5.19 \\
\hline
\end{tabular}




\subsection{FTIR results}

The AA2024-T3 panel surface exposed for $72 \mathrm{~h}$ to a $3.5 \%(\mathrm{w} / \mathrm{v}) \mathrm{NaCl}$ solution containing 500 ppm $\mathrm{H}_{2}$ DCTZ, was mapped by FTIR using a microscope attachment. The FTIR map concentrated on a region in the vicinity of a corrosion pit outlined in Fig 6a. Fig 6c shows the spectrum taken from 6 different points as identified in Fig. $6 \mathrm{~b}$ with the $1^{\text {st }}$ mark close to the pit edge and each mark sequentially moving away from this point. The distance between each mark is approximately $50 \mu \mathrm{m}$. The band at $3500 \mathrm{~cm}^{-1}$ corresponds to the $-\mathrm{OH}$ functionality which confirms the traces of water on the sample (Fig 6).

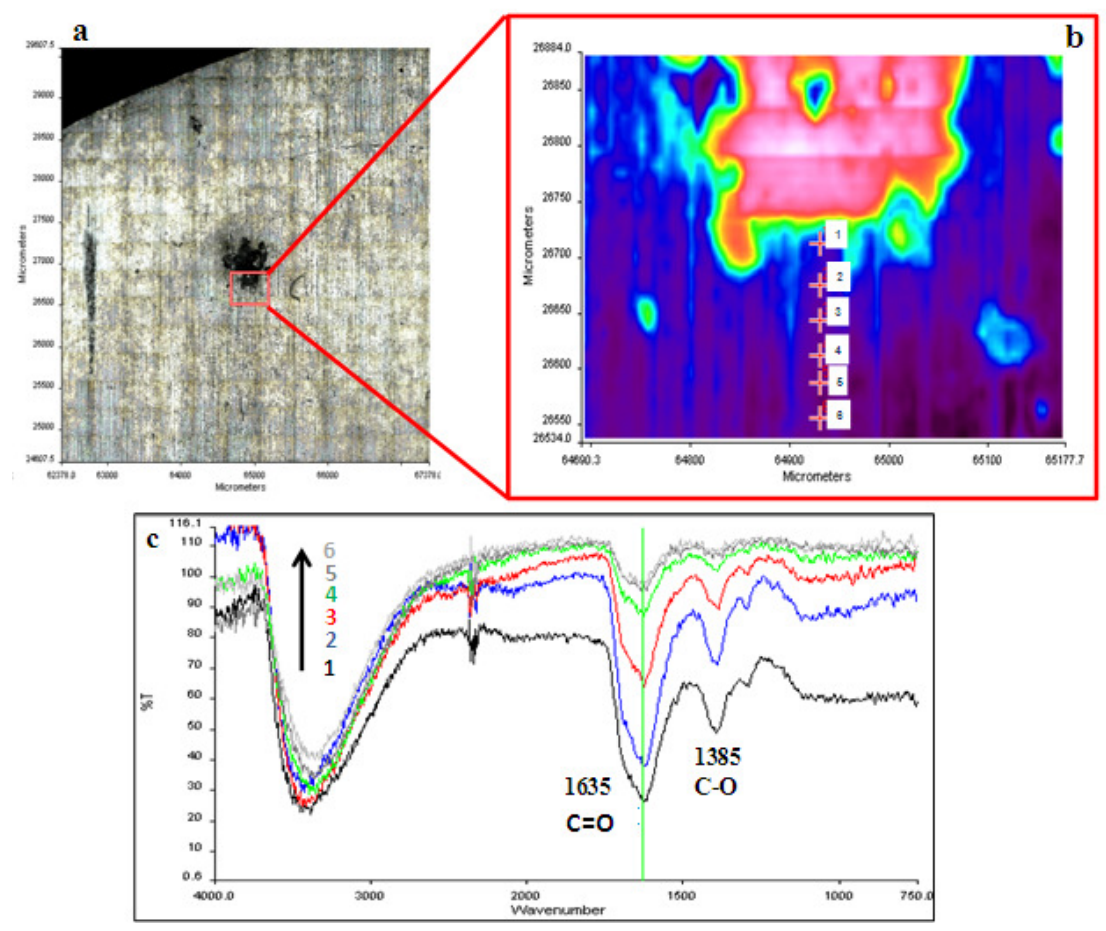

Fig.6. FTIR spectrum of the panel following exposure to $500 \mathrm{ppm}$ of $\mathrm{H}_{2} \mathrm{DCTZ}$ containing chloride solution exposed for $72 \mathrm{~h}$ sample, (a) The FTIR mapping was completed in the area marked as red rectangle, (b) Different marks (6), close to pit (1 ${ }^{\text {st }}$ mark) and each mark consecutively moving away from the pit, (c) FTIR spectrum from these different 6 marks. 
There is no significant band observed at the $3500 \mathrm{~cm}^{-1}$ region in the sample, however a weak signal observed in Fig. 7. The spectra are dominated by a band at $1635 \mathrm{~cm}^{-1}$ potentially representing superposition of carboxylic $(\mathrm{C}=\mathrm{O})$ and aromatic cyclic double bonds and the carboxylic C-O stretch at $1385 \mathrm{~cm}^{-1}$. It is interesting to note that the intensity of both bands decreases with increasing distance from the pit. This result infers that the $\mathrm{H}_{2} \mathrm{DCTZ}$ has an affinity for the pit and its surrounding area. Fig 7 shows the FTIR mapping of AA2024 surface exposed to chloride solution without organic inhibitor. As expected the spectrum (Fig 7c) does not show any significant intensity change between the pit and the surface, although a baseline shift was observed. This shift is most likely due to a rough surface profile at the pit. There was no signal observed for $\mathrm{N}-\mathrm{H}$ in the region of $3300 \mathrm{~cm}^{-1}$ (Highlighted by black rectangular in Fig $7 \mathrm{c})$.

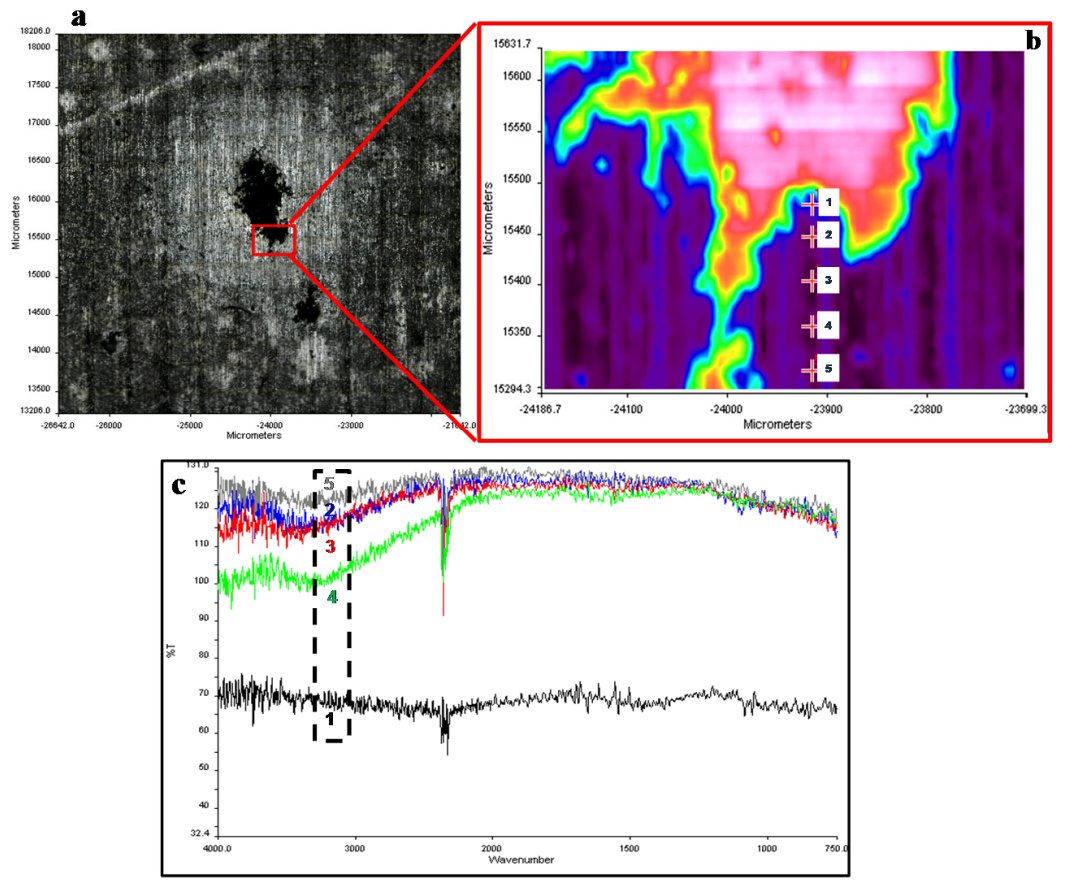

Fig. 7. The FTIR mapping of AA 2024 surface exposed to chloride solution without organic inhibitor, (a) The FTIR mapping was completed in the area marked as red rectangle, (b) Different 
marks (6), close to pit ( $1^{\text {st }}$ mark) and each mark consecutively moving away from the pit, (c) FTIR spectrum from these different 6 marks (black rectangle indicates the absence of the NH signals)

\subsection{FE-SEM-EDX results}

The corrosion mechanism of AA2024 alloy has been well researched in the past and it is known that the anodic $\mathrm{S}$ phase particles $\left(\mathrm{Al}_{2} \mathrm{CuMg}\right)$ distributed in the alloy cause severe pitting of the alloy when exposed to a chloride-containing environment $[38,39,40]$. During immersion of alloy in a chloride rich electrolyte, the $\mathrm{S}$ phase particles experience de-alloying of magnesium $(\mathrm{Mg})$ and aluminium $(\mathrm{Al})$ leaving behind a residue enriched with copper $(\mathrm{Cu})$ and oxygen $(\mathrm{O})$ [41]. Elemental analysis of the pit region where the elevated presence of $\mathrm{H}_{2} \mathrm{DCTZ}$ was already confirmed by FTIR analysis was performed by SEM-EDX. Fig. 8 shows the EDX signal intensities for $\mathrm{Cu}, \mathrm{Al}$ and $\mathrm{O}$ in the corroded region. It was noted that the intensity of $\mathrm{Cu}$ is higher in and around the pit region and less elsewhere.

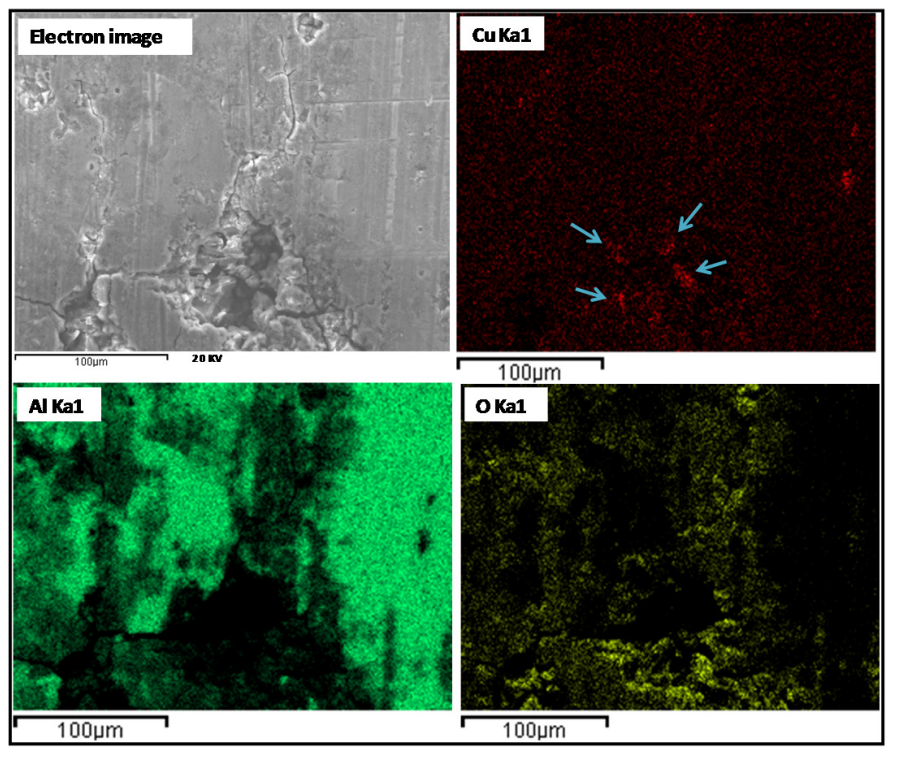


Fig.8. SEM/ EDX ray dot mapping of $\mathrm{Cu}, \mathrm{Al}$ and $\mathrm{O}$ performed in the corrosion pit region, which was formed when exposed to $500 \mathrm{ppm} \mathrm{H}_{2}$ DCTZ containing chloride solution for $72 \mathrm{~h}$ [blue arrows marking copper rich areas].

Analysis of the metal surface around the clearly defined pit supports the postulate that $\mathrm{H}_{2} \mathrm{DCTZ}$ is bonding with $\mathrm{Cu}$ remnants from the de-alloying S-phase particles. There was no evidence of other intermediate particles (Fe, Mn and $\mathrm{Si}$ ) observed around the pit by SEM-EDX (not shown). Previous research on organic corrosion inhibitors found synergistic relationships between inhibitor structures and the mechanism of their adsorption [42]. The adsorption mainly depends on certain physiochemical properties of the inhibitor molecule such as functional groups, steric factors, aromaticity and also on the electronic structure of the molecules. However in the case of $\mathrm{H}_{2}$ DCTZ, a mechanism similar to benzotriazole (BTA) could be possible, where the formation of $\mathrm{Cu}-\mathrm{N}$ coordinate bonds is favoured between the tetrazine and the copper rich substrate.

\subsection{Antibacterial assay}

\subsubsection{Effect of $\mathrm{H}_{2} \mathrm{DCTZ}$ on bacterial growth}

In order to study the $\mathrm{H}_{2} \mathrm{DCTZ}$ antibacterial activity, $\mathrm{MIC}, \mathrm{MBC}$ and kinetic assays were carried out at various concentrations $(32,63,125,250$, and $500 \mathrm{ppm})$. In the case of Gram positive bacteria, S. aureus growth was inhibited by between 32.1 and $100 \%$ (Table 2). 
Table 2: Percentage growth inhibition of $S$. aureus and E. coli in the presence of different concentrations $(32,63,125,250$ and $500 \mathrm{ppm})$ of $\mathrm{H}_{2} \mathrm{DCTZ}$

\begin{tabular}{llllll}
\hline Microorganism & \multicolumn{5}{c}{ Concentrations (ppm) } \\
\cline { 2 - 6 } & $\mathbf{5 0 0}$ & $\mathbf{2 5 0}$ & $\mathbf{1 2 5}$ & $\mathbf{6 3}$ & $\mathbf{3 2}$ \\
\hline S. aureus ATCC 25923 & $100 \pm 0$ & $100 \pm 0$ & $54.2 \pm 7.1$ & $42.7 \pm 0.5$ & $32.1 \pm 3.7$ \\
& & & & & \\
E. coli ATCC 25922. & $64.3 \pm 4.6$ & $57.3 \pm 7.8$ & $50.8 \pm 5.1$ & $48.1 \pm 2.6$ & $35.4 \pm 8.3$ \\
& & & & & \\
\hline
\end{tabular}

The efficacy increases and reached $100 \%$ at a concentration of $250 \mathrm{ppm}$ of $\mathrm{H}_{2} \mathrm{DCTZ}$, as characterised by complete inhibition of bacterial growth. Thus the MIC value is $250 \mathrm{ppm}$. Below $250 \mathrm{ppm}$ there was a variation with $54.2 \%, 42.7 \%$ and $32.1 \%$ inhibition achieved at 125, 63 and 32 ppm respectively (Table2). The modified imprint method proved that the MBC values of $\mathrm{H}_{2}$ DCTZ are similar to its MIC value of 250 ppm against $S$. aureus (Fig.9). Gram negative bacteria $E$. coli showed moderate antibacterial activities, varying from 35.4 to $64.3 \%$ inhibition at the same concentration of $\mathrm{H}_{2} \mathrm{DCTZ}$ (32 to $500 \mathrm{ppm}$ ).

\subsubsection{Kinetics growth curve of bacteria in the presence of $\mathrm{H}_{2} \mathrm{DCTZ}$}

The growth curves of the S. aureus (Fig.9) showed growth delays in the presence of different concentrations of $\mathrm{H}_{2} \mathrm{DCTZ}$, with solutions of 250 and 500 ppm completely inhibiting growth over the entire $24 \mathrm{~h}$ period. Even at $125 \mathrm{ppm}$ the compound was effective at delaying growth for $12 \mathrm{~h}$. Generally, the increase in lag time between concentrations of compound was observed to be more marked than the decrease in growth rate, which was more gradual. 


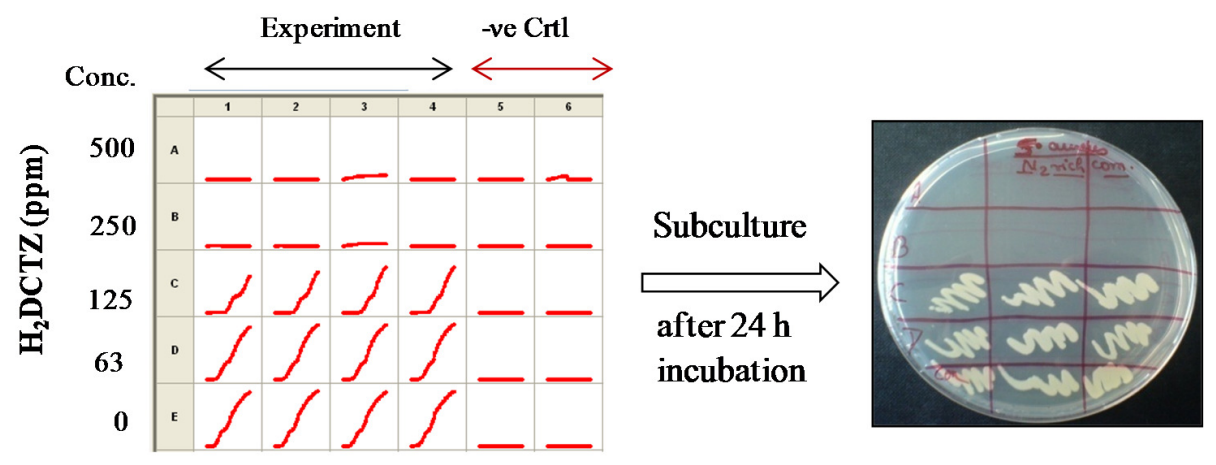

Fig 9. Kinetic growth curve profile of S. aureus ATCC 25923 over 24 h treated with different concentrations $(500,250,125,63$ and $0 \mathrm{ppm})$ of $\mathrm{H}_{2} \mathrm{DCTZ}$ and agar plate shows MBC value where A, B, C, D, and control indicates different concentrations (500, 250, 125and 63 ppm) of compound respectively.

A higher effectiveness of the nitrogen rich tetrazine against Gram positive bacteria S. aureus as compared to Gram negative bacteria E. coli was observed. It is well know that Gram positive bacteria are more susceptible to antimicrobial agents than Gram negative bacteria. This may be attributed to the constitutional differences in the cell membrane as Gram negative bacteria are characterised by a thin peptidoglycane layer supported externally by an outer membrane made up of lipopolysacaharides and phospholipids. The presence of porin proteins in this outer layer probably retards the passage of nitrogen rich compounds inside the bacterial cell [35]. As this outer membrane is absent in Gram positive bacteria damage to the cell membrane is more likely.

\subsubsection{Assessment of bacterial damage by chemical assay}

The level of MDA (measured by adsorption at $530 \mathrm{~nm}$ ) in the supernatant of tetrazine-treated bacterial suspensions, when compared to untreated equivalents, indicated bacterial cell wall or membrane damage. Fig.10 shows the higher release of MDA from cells treated with the $\mathrm{H}_{2} \mathrm{DCTZ}$ when compared to untreated bacteria. 


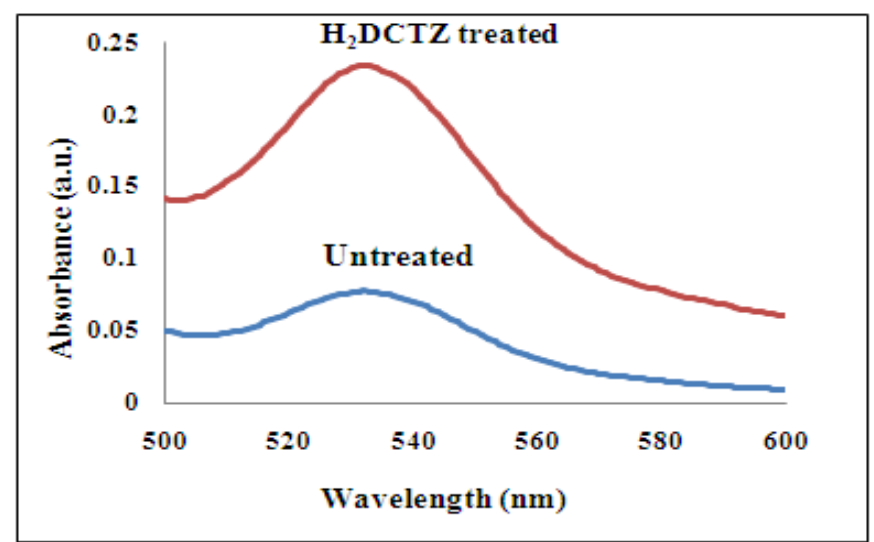

Fig.10. Estimation of release of malondialdehyde (MDA) in S. aureus ATCC 2592 in the presence and absence of $\mathrm{H}_{2} \mathrm{DCTZ}$ at $250 \mathrm{ppm}$

These results confirm the damage of bacterial cell envelope in the presence of the $\mathrm{H}_{2} \mathrm{DCTZ}$ at the particular concentration $(250 \mathrm{ppm})$.This is to be expected with nitrogen rich molecules.

\section{Conclusion}

The results from this study indicate that $72 \mathrm{~h}$ exposure of aluminium alloy (AA 2024-T3) to 500 ppm of $\mathrm{H}_{2}$ DCTZ containing chloride rich electrolyte showed less corrosion activity when compared to a blank sample. This is due to the presence of corrosion inhibitor in the solution which prevented electrochemical activity. It was found that the FTIR signal intensity of the tetrazine ring decreases with increasing distance from the corrosion pit proving that the $\mathrm{H}_{2} \mathrm{DCTZ}$ has an affinity for the pit and its anodic surroundings. FE-SEM/EDX experiments confirmed the elevated $\mathrm{Cu}$ layers within the pit. Apart from anticorrosion effects, moderate antibacterial activity $(57.3 \pm 7.8 \%)$ was observed against environmental bacteria $E$. coli with complete biocidal efficacy against $S$. aureus in the presence of $\mathrm{H}_{2}$ DCTZ (250 ppm). 24 h kinetic growth curves of $S$. aureus showed complete inhibition of bacteria in the presence of $\mathrm{H}_{2} \mathrm{DCTZ}$ (250 ppm). Biocidal efficacy was also confirmed using a modified imprint method. The antibacterial activity was proven to result from cell damage mechanism using the TBA assay, whereby treated 
S. aureus formed a strong pink coloured MDA-TBA adduct. This work indicates that the $\mathrm{H}_{2}$ DCTZ tetrazine would be a suitable additive in a protective coating for many environmental applications. It would be of particular interest to the aerospace industry where active corrosion inhibitors capable of preventing bacterial colonization of materials are required, such as for fuel delivery components.

\section{Acknowledgment}

The authors would like to thanks Enterprise Ireland for financial support through the Commercialisation Fund project Sol E-coat (CFTD/07/346) and the Applied Research Enhancement (ARE (2008/RE/05)) program. The authors are grateful to Ms Emer Ryan for her excellent SEM assistance.

\section{Reference}

1 N.G. Thompson, D.J. Dunmire, M. Yunovich, Corrosion costs and maintenance strategies-A civil/industrial and government partnership, Materials performance, 44 (2005) 16-21.

2 G.S. Frankel, Mechanism of Al alloy corrosion and the role of chromate inhibitors, AFOSR Multidisciplinary University Research Initiative, F49620-96-1-0479, 2001.

3 M. Kendig, R. Buchheit, Corrosion inhibition of aluminum and aluminum alloys by soluble chromates, chromate coatings, and chromate-free coatings, Corrosion, 59 (2003) 379-400.

4 R. Buchheit, A. Hughes, Chromate and chromate-free conversion coatings, ASM handbook, 13 (2003) 720-735.

5 G. Moretti, G. Quartarone, A. Tassan, A. Zlngales, 5-Amino- and 5-chloro-indole as mild steel corrosion inhibitors in $1 \mathrm{~N}$ sulphuric acid, Electrochimica Acta, 41 (1996) 1971-1980. 
6 A. Chetouani, A. Aouniti, B. Hammouti, N. Benchat, T. Benhadda, S. Kertit, Corrosion inhibitors for iron in hydrochloride acid solution by newly synthesised pyridazine derivatives, Corrosion Science, 45 (2003) 1675-1684.

7 F. Bentiss, F. Gassama, D. Barbry, L. Gengembre, H. Vezin, M. Lagrenée, M. Traisnel, Enhanced corrosion resistance of mild steel in molar hydrochloric acid solution by 1,4-bis(2pyridyl)-5H-pyridazino[4,5-b]indole: Electrochemical, theoretical and XPS studies, Applied Surface Science, 252 (2006) 2684-2691.

8 H. Tian, W. Li, K. Cao, B. Hou, Potent inhibition of copper corrosion in neutral chloride media by novel non-toxic thiadiazole derivatives, Corrosion Science, 73 (2013) 281-291.

9 R. Ezabadi, C. Camoutsis, P. Zoumpoulakis, A. Geronikaki, M. Soković, J. Glamočilija, A. Ćirić, Sulfonamide-1,2,4-triazole derivatives as antifungal and antibacterial agents: Synthesis, biological evaluation, lipophilicity, and conformational studies, Bioorganic \& Medicinal Chemistry, 16 (2008) 1150-1161.

10 Y.A. Al-Soud, M.N. Al-Dweri, N.A. Al-Masoudi, Synthesis, antitumor and antiviral properties of some 1,2,4-triazole derivatives, Il Farmaco, 59 (2004) 775-783.

11 S.N. Pandeya, R. Kumar, A.K. Pathak, G. Nath, Synthesis and biological evaluation of triazine derivatives, Der Pharma Chemica, 2 (2010) 257-266.

12 A. R. Katritzky, Handbook of Heterocyclic Chemistry, Pergamon Press, Oxford, 1986.

13 L. Elkadi, B. Mernari, M. Traisnel, F. Bentiss, M. Lagrenée, The inhibition action of 3,6bis(2-methoxyphenyl)-1,2-dihydro-1,2,4,5-tetrazine on the corrosion of mild steel in acidic media, Corrosion Science, 42 (2000) 703-719. 
14 S. Jaiswal, P.C.R. Varma, L. O'Neill, B. Duffy, P. McHale, An investigation of the biochemical properties of tetrazines as potential coating additives, Materials Science and Engineering: C, 33(2013) 1925-1934.

15 M. Whelan, K. Barton, J. Cassidy, J. Colreavy, B. Duffy, Corrosion inhibitors for anodised aluminium, Surface and Coatings Technology, 227 (2013) 75-83.

16 J. Mohan, Facile synthesis and aantimicrobial activity of spirobicyclo[3.2.1]octane-2',3-(4h)[2h]-thiazolo[3,2-b]-s-tetrazines, Organic Preparations and Procedures International, 24 (1992) 523-525.

17 W.-X. Hu, G.-W. Rao, Y.-Q. Sun, Synthesis and antitumor activity of s-tetrazine derivatives, Bioorganic \& Medicinal Chemistry Letters, 14 (2004) 1177-1181.

18 B. Chaturvedi, N. Tiwari, , Nizamuddin, A convenient and novel synthesis of 1, 2, 4triazolo[3, 4-b][1, 3, 4]thiadiazoles as potential pesticides, Agricultural and Biological Chemistry. 52 (1988) 1229-1232.

19 D. Nhu, S. Duffy, V.M. Avery, A. Hughes, J.B. Baell, Antimalarial 3-arylamino-6benzylamino-1,2,4,5-tetrazines, Bioorganic \& Medicinal Chemistry Letters, 20 (2010) 44964498.

20 G.J. Bridger, E.J. Mceachern, R. Skerlj, D. Schols, K. Skupinska, G. Chen, Y. Zhu, C. Harwig, A. Kaller, I. Baird, Chemokine receptor binding heterocyclic compounds with enhanced efficacy, in, EP Patent 2,374,804 (2011).

21 S.K. Pandey, A. Singh, A. Singh, Nizamuddin, Antimicrobial studies of some novel quinazolinones fused with [1,2,4]-triazole, [1,2,4]-triazine and [1,2,4,5]-tetrazine rings, European Journal of Medicinal Chemistry, 44 (2009) 1188-1197. 
22 W.-X. Hu, G.-W. Rao, Y.-Q. Sun, Synthesis and antitumor activity of s-tetrazine derivatives, Bioorganic \& Medicinal Chemistry Letters, 14 (2004) 1177-1181.

23 M.E. Rauch, H.W. Graef, S.M. Rozenzhak, S.E. Jones, C.A. Bleckmann, R.L. Kruger, R.R. Naik, M.O. Stone. Characterization of microbial contamination in United States Air Force aviation fuel tanks. Journal of Industrial Microbiology \& Biotechnology, 33 (2006) 29-36.

24 D.L. Boger, J.S. Panek, M. Patel, Preparation and diels-alder reaction of a reactive, electrondeficient heterocyclic azadiene: dimethyl 1,2,4,5-tetrazine-3,6- Dicarboxylate. 1,2-diazine (dimethyl 4-phenyl-1,2- diazine-3,6-dicarboxylate) and pyrrole (dimethyl 3- phenylpyrrole2,5-dicarboxylate) introduction. Organic Synthesis 70 (1992) 79-92.

25 D.L. Boger, R.S. Coleman, J.S. Panek, F.X. Huber, J. Sauer, A detailed, convenient preparation of dimethyl 1,2,4,5-tetrazine-3,6-dicarboxylate. The Journal of Organic Chemistry 50 (1985) 5377-5379.

26 D.L. Boger, J.S. Panek, M. Patel, Preparation and diels-alder reaction of a reactive, electrondeficient heterocyclic azadiene: dimethyl 1,2,4,5-tetrazine-3,6- Dicarboxylate. 1,2-diazine (dimethyl 4-phenyl-1,2- diazine-3,6-dicarboxylate) and pyrrole (dimethyl 3- phenylpyrrole2,5-dicarboxylate) introduction. Organic Synthesis 70 (1992) 79-92.

27 P.C.R. Varma, B. Duffy, J. Cassidy, Influence of magnesium nitrate on the corrosion performance of sol-gel coated AA2024-T3 aluminium alloy, Surface and Coatings Technology, 204 (2009) 277-284.

28 D.D. Macdonald, Reflections on the history of electrochemical impedance spectroscopy, Electrochimica Acta, 51 (2006) 1376-1388. 
29 S. Jaiswal, B. Duffy, A.K. Jaiswal, N. Stobie, P. McHale, Enhancement of the antibacterial properties of silver nanoparticles using $\beta$-cyclodextrin as a capping agent, International Journal of Antimicrobial Agents, 36 (2010) 280-283.

30 A.K. Jaiswal, G. Rajauria, N. Abu-Ghannam, S. Gupta, Effect of different solvents on polyphenolic content, antioxidant capacity and antibacterial activity of Irish York cabbage, Journal of Food Biochemistry, 36 (2011) 344-358.

31 S. Jaiswal, K. Bhattacharya, M. Sullivan, M. Walsh, B. Creaven, F. Laffir, B. Duffy, P. McHale, Non-cytotoxic antibacterial silver-coumarin complex doped sol-gel coatings, Colloids and Surfaces B: Biointerfaces, 102 (2013) 412-419.

32 K. Grintzalis, D. Zisimopoulos, T. Grune, D. Weber, C.D. Georgiou, Method for the simultaneous determination of free/protein malondialdehyde and lipid/protein hydroperoxides, Free Radical Biology and Medicine, 59 (2013) 27-35,

33 R. Zamora, M. Alaiz, F.J. Hidalgo, Feed-back inhibition of oxidative stress by oxidized lipid/amino acid reaction products, Biochemistry, 36 (1997) 15765-15771.

34 J.R. Requena, M.X. Fu, M.U. Ahmed, A.J. Jenkins, T.J. Lyons, J.W. Baynes, S.R. Thorpe, Quantification of malondialdehyde and 4-hydroxynonenal adducts to lysine residues in native and oxidized human low-density lipoprotein, Biochemical Journal, 322 (1997) 317.

35 S. Singh, P. Patel, S. Jaiswal, A. Prabhune, C. Ramana, B. Prasad, A direct method for the preparation of glycolipid-metal nanoparticle conjugates: sophorolipids as reducing and capping agents for the synthesis of water re-dispersible silver nanoparticles and their antibacterial activity, New Journal of Chemistry, 33 (2009) 646-652. 
36 P.C.R. Varma, J. Colreavy, J. Cassidy, M. Oubaha, C. McDonagh, B. Duffy, Corrosion protection of AA 2024-T3 aluminium alloys using 3, 4-diaminobenzoic acid chelated zirconium-silane hybrid sol-gels, Thin Solid Films, 518 (2010) 5753-5761.

37 M.R. Bagherzadeh, T. Mousavinejad. Preparation and investigation of anticorrosion properties of the water-based epoxy-clay nanocoating modified by $\mathrm{Na}^{+} \mathrm{MMT}$ and Cloisite 30B. Progress in Organic Coatings, 74 (2012) 589-595.

38 R. Buchheit, R. Grant, P. Hlava, B. McKenzie, G. Zender, local dissolution phenomena associated with $\mathrm{S}$ phase $\left(\mathrm{Al}_{2} \mathrm{CuMg}\right)$ particles in aluminum alloy 2024-T3, Journal of the Electrochemical Society, 144 (1997) 2621-2628.

39 G. Chen, M. Gao, R. Wei, Microconstituent-induced pitting corrosion in aluminum alloy 2024-T3, Corrosion, 52 (1996) 8-15.

40 D. Zhu, W.J. van Ooij, Corrosion protection of AA 2024-T3 by bis-[3-(triethoxysilyl) propyl] tetrasulfide in sodium chloride solution.: Part 2: mechanism for corrosion protection, Corrosion Science, 45 (2003) 2177-2197.

41 M. Vukmirovic, N. Dimitrov, K. Sieradzki, Dealloying and Corrosion of Al Alloy 2024 T 3, Journal of The Electrochemical Society, 149 (2002) B428-B439.

42 M. Lagrenée, B. Mernari, N. Chaibi, M. Traisnel, H. Vezin, F. Bentiss, Investigation of the inhibitive effect of substituted oxadiazoles on the corrosion of mild steel in $\mathrm{HCl}$ medium, Corrosion Science, 43 (2001) 951-962. 